\title{
Takayuki Tamura
}

1919-2009

\section{The Editors}

Received: 2 July 2009 / Published online: 8 August 2009

(C) Springer Science+Business Media, LLC 2009

The editors regret to have to announce that Professor Takayuki Tamura died on June 1, 2009. Professor Tamura was a major contributor to the early development of the Theory of Semigroups. The Tribute to be found in the pages that follow had been prepared prior to his death and was scheduled to be published in this issue of Semigroup Forum. 